\title{
Recycling of Organic Waste for its Potential to be Used as Fertilizer
}

\author{
Imran Ali Khan', Waleed Asghar ${ }^{1}$, Abdul Latif ${ }^{2}$, Jawad Ali ${ }^{1}$, Farasat Ali ${ }^{1}$, Aziz Ahmad ${ }^{1}$, Kamran Ali Khan${ }^{1}$, \\ Muhammad Umer Aziz ${ }^{1}$ and Farhan Iftikhar ${ }^{3}$
}

${ }^{1}$ School of Environment, Beijing Normal University, China

${ }^{2}$ School of Resource and Environment, Anhui Agricultural University, China

${ }^{3}$ Gomal University Dera Ismail Khan, Pakistan

Submission: September 18, 2018, Published: October 16, 2018

"Corresponding author: Waleed Asghar, School of Environment, Beijing Normal University, Beijing 100875, China; Tel: +8613126825879; Email: waleedasghar978@gmail.com

\begin{abstract}
Recycling of organic waste for the application of fertilizer, is essential for feasible supplement administration. Phosphorous (P) extractability of composted and fresh manure amended soil appeared that the $\mathrm{P}$ forms changed essentially during the experiment. This study aims to present information regarding bioavailability of nutrients to maize crop from soils amended with different waste materials using the Hadley sequential fractionation method. Squander things from 4 distinct sources, contains animal waste fresh (AWF), animal waste compost (AWC), mixed waste fresh (MWF), and mixed waste compost (MWC) chosen to decide the diverse portions of phosphorus. The phosphorus was step wise fractionated into water solvent separated $\mathrm{P}\left(\mathrm{H}_{2} \mathrm{O}-\mathrm{P}\right)$, plant accessible $\left(\mathrm{NaHCO}_{3}-\mathrm{P}\right)$, Al partners ( $\left.\mathrm{NaOH}-\mathrm{P}\right)$, Ca related $(\mathrm{HCl}-\mathrm{P})$ leftover structures. The general $\mathrm{P}$ divisions separated by reagents fluctuated arranged by $\mathrm{HCl}>\mathrm{NaOH}>\mathrm{NaHCO}_{3}>\mathrm{H}_{2} \mathrm{O}$. Logical outcomes demonstrated that fertilizing the soil of creature composts upgraded $\mathrm{P}$ accessibility and enhanced plant sustenance. The utilization of treated the soil creature composts as soil correction can be monetarily beneficial and will possibly improve the significant alarms related with natural waste.
\end{abstract}

Keywords: Animal manure; Mixed waste; Phosphorus; Soil; Sustainability

Abbreviations: AWF: Animal Waste Fresh; AWC: Animal Waste Compost; MWF: Mixed Waste Fresh; MWC: Mixed Waste Compost; PL: Poultry Litter; EC: Electrical Conductivity

\section{Introduction}

Phosphorus (P) is viewed as basic supplement for plants without which they neglect to finish their whole remember cycle. It is essential in extensive sum by plants for the amalgamation of particles and different mixes of active cells like phospholipids, deoxyribonucleic, ribonucleic acid, sugar phosphate and last but not the least in involvement in synthesis of energy rich compounds in living cells Havlin [1]. Faridullah et al. [2], detailed that transfer of poultry litter (PL) is one of the real worries of poultry agriculturists. Consuming of PL is a monetarily suitable and earth safe technique for poultry squander administration. Phosphorus (P) fractionation in squander material is essential for anticipating its profile accessibility. Phosphorus was partial into promptly plant-accessible $\mathrm{P}$, inorganic $\mathrm{P}$ (another plant-accessible portion), sesquioxide-related $\mathrm{P}$, and Ca-related $\mathrm{P}$ by consecutively extricating with deionized water. The inorganic $\mathrm{P}$ was additionally decided utilizing Peterman citrus extract and citrus extract extractions. Misfortune on-start, electrical conductivity (EC), and pH were estimated. Huang et al. [3], assessed the rehashed use of composts to agrarian soil, and concentrated the gathering of phosphorus ( $p$ ) in soil, be that as it may, it is hazy if excrement Pmk can carry on like $P$ in solvent manures in aggregation Olsen-P $\left(0.5 \mathrm{~mol} \mathrm{NaHCO}_{3}\right.$ at $\mathrm{pH}$ 8.5) in soil. A long haul wheat maize pivot explore was directed to research the impacts of detailed utilization of excrements on P aggregation in the dirt, the outcome demonstrated that over the top or remaining P in soil prompted increment of Olsen-P in soil, $\mathrm{P}$ treatment rate, trim yield, soil $\mathrm{pH}$ and development time. The impacts of use of $\mathrm{K}$ manures or maize straw to soils or supplanting of maize with soybean in wheat editing framework were not noteworthy on soil on soil Olsen-P aggregation. The aggregation rates of soil Olsen-P were represented by $\mathrm{P}$ application rates of solvent $\mathrm{P}$ composts and $\backslash$ or fertilizers. Comparative pattern of Olsen-p aggregation was found in soil with dissolvable $\mathrm{P}$ composts just or in addition to excrements $\mathrm{P}$, which provided confirm that conduct of excrement $\mathrm{P}$ in long haul field soils is like inorganic $P$ manures and are useful for the best administration of soil P in farming creation and condition generation. Phosphorous extractability in composts amended soil is therefore important to predict their bioavailability. The portrayal of $\mathrm{P}$ in poultry squander and other natural waste may empower us to discover the conduct and destiny of $\mathrm{P}$ and to recognize maintainable field administration practices to lessen conceivable $\mathrm{P}$ loses. The vast majority of the examinations including fertilizer 
have been directed on the impact of crisp and treated the soil poultry on plant sustenance. Fertilizers are viewed as a significant item that can be utilized as a wellspring of soil change and natural issue in agrarian land. The utilization of treated the soil creature excrement has expanded throughout the years. This training enhances the nature of the harvests and jelly the earth $[4,5]$. Maftoun et al. [6], assessed the effect of two natural squanders and phosphorus (P) on the development, essential arrangement of spinach (Spinacia oleracea L.) and soil substance possessions. Medicines comprised of 4 stages of civil waste fertilizer, MWC (0, 1 , 2 , and $4 \%)$, five rates of poultry excrement, $\mathrm{PM}(0,1,2,3$, and $4 \%)$, and $3 \mathrm{P}$ levels $(0,25$, and $50 \mathrm{mg} \mathrm{kg}-1$ as $\mathrm{KH} 2 \mathrm{PO} 4)$. Poultry litter is normally viewed as a waste item that is high in phosphorus, $\mathrm{K}, \mathrm{Ca}$ and Mg. Due to this land application of the manure and litter from poultry as fertilizer for crops has been the most cost-effective method of disposing of the large amounts of manure and litter that have been produced annually Sharpley \& Moyer [7]. Faridullah et al. [2,8], characterized the total P contained in manures and litter into organic and inorganic $\mathrm{P}$ fractions via sequential extraction with water, dilute bases $\left(\mathrm{NaOH}, \mathrm{NaHCO}_{3}\right)$ and acid $(\mathrm{HCl})$ using a modification of the soil $\mathrm{P}$ fractionation previously described by Hedley et al. [9].

\section{Materials and Methods}

\section{Site description}

The examples were gathered from various regions of GilgitBaltistan (Figure 1A). The Gilgit-Baltistan is situated in northern territories of Pakistan, includes around 72,696sq km zone and gives home to a human populace of almost around 1.8 million individuals. In Gilgit, no arranged waste administration framework is accessible in any of the urban communities; additionally, absence of mindfulness wins among different partners including overall population, businesspeople/producers and waste directors in regard to isolation and decrease of waste at source and accessible substitute choices.

\section{Materials}

Four different sources of the samples include: Animal Waste Fresh (AWF), Animal Waste Compost (AWC), Mixed Waste Fresh (MWF) and Mixed Waste Compost (MWC). These examples were air dehydrated, smashed and sieved ( $<250$ micron) to guarantee similarity (Figure 1B). Air dried examples were broiler dehydrated at $105^{\circ} \mathrm{C}$ for 24 hours. After the stove dry, examples were permitted to chill off for 30 minutes. Distinctive parts of Phosphorus were resolved. The waste material altered with soil was broke down for significant compound properties. Phosphorus and some different supplements were additionally decided. Dampness content in the dirt examples were balanced by stove drying couple of grams of soil. A trace element concentration in the soil was determined with an atomic absorption spectrometer.

\section{Pot experiments}

The neighborhood soil from the Gilgit city was utilized amid the pot test. The test was directed in the office of CIIT Abbottabad under green glass house form. Tests were blended with the nearby soil in the segments. Maize plant in all pots was developed for two months to assess the water dissolvable, extractable and add up to $\mathrm{P}, \mathrm{K}, \mathrm{Ca}, \mathrm{Mg}, \mathrm{Zn}, \mathrm{Ni}, \mathrm{Cu}$, and Fe fixation in plant tissues. $5 \mathrm{~kg}$ of each dirt example was evaluated into pot. Water system was completed by the measuring technique. As a matter of first importance, research facility trial was done to check the water system water necessity (pot limit) of each fertilizer revised soils. To decide the water system prerequisite, two pots for every treatment were weighed consistently. The required measure of water system water was computed from the distinction between pot limits. The amount of water connected to pots was controlled by the necessity of every treatment. Pots were rearranged after $48 \mathrm{hr}$ to stay away from micro climatic impacts. Every treatment was duplicated two times. Plants were gained, wash away with refined water and broiler dried at $65{ }^{\circ} \mathrm{C}$ for 48 hours to decide plant dry issue. From there on, plant tests were ground sieved $(0.5 \mathrm{~mm})$ to quantify the substance of $\mathrm{P}, \mathrm{K}, \mathrm{Ca}, \mathrm{Mg}$ or more specified follow components. Plants were reaped, washed with refined water and broiler dehydrated at $65{ }^{\circ} \mathrm{C}$ for 48 hours to decide plant dry issue. From there on, plant tests were ground sieved $(0.5 \mathrm{~mm})$ to quantify the substance of $\mathrm{P}, \mathrm{K}, \mathrm{Ca}, \mathrm{Mg}$ or more specified follow elements.

\section{Phosphorus fractionations}

The examples were evaluated $(0.5 \mathrm{~g})$ were put in axis tube. Phosphorus parts were controlled by the altered consecutive removal method of Hedley et al. [9], as portrayed by [10,11] (Figure 1C). The examples weighing $0.5 \mathrm{~g}$ were put in $50 \mathrm{ml}$ rotator tube and were fractionated in to promptly Plant Available P, Alrelated $\mathrm{P}, \mathrm{Ca}$ related $\mathrm{P}$ and $\mathrm{HCl}$ related $\mathrm{P}$ by successive removal with $30 \mathrm{ml}$ de-ionized water $0.5 \mathrm{M} \mathrm{NaHCO}{ }_{3}, 1 \mathrm{MNaOH}$ and $1 \mathrm{MHCl}$ individually. For every removal, the material shakes for $16 \mathrm{~h}$ at room temperature. After each conclusion to-end shaking the tubes centrifuged at 10,000rpm for 10 minutes, and the supernatants was sifted by a $0.2 \mu \mathrm{m}$ channel. The shaking/sifting cycle was rehashed for every one of the concentrates.

\section{Analysis}

The P resolved on a spectrophotometer utilizing the phosphomolybdate blue strategy Murphy and Riley [12]. Absorbance resolved at a wavelength of $710 \mathrm{~nm}$. Tests duplicated two times. The substance of $\mathrm{K}, \mathrm{Ca}, \mathrm{Mg}$ and some follow components were resolved utilizing an energized Zeeman nuclear assimilation spectrophotometer (Model Z-2300, Hitachi, Japan). The data was investigated statistically.

\section{Results and Discussion}

Phosphorous (P) extractability of composted and fresh manure amended soil demonstrated that the P shapes changed essentially amid the examination. The total concentration of phosphorous fractionation considerably changed as $\mathrm{HCl}>\mathrm{NaOH}>\mathrm{NaHCO}_{3}>\mathrm{H}_{2} \mathrm{O}$ (Table 1). The mean levels for the arrival of aggregate phosphorus got in compost changed as AWF (Animal Waste Fresh) $>$ AWC (Animal Waste Compost) $>$ MWC (Mixed Waste Compost) $>M W F$ (Mixed Waste Fresh) (Figure 1). The quality of civil solid waste manure is reliant on numerous wellsprings of variation including the treating the soil office idea, feed stock foundation and extents used, fertilizing the soil strategy, and size of development. 
Hargreave [13]. Whereas P level in the soil amended with the waste product was highest in AWF (90.1 $\mathrm{mg} \mathrm{kg}^{-1}$ ) and lowest in MWF (81.4mg kg-1) while maximum was in post-harvest soil in AWF (85.4mg kg-1) and minimum in AWC (75 $\mathrm{mg} \mathrm{kg}^{-1}$ ) (Table 1). The water soluble extracted $P$ in manure increased in order of AWC $>$ MWC $>$ MWF $>$ AWF, (Figure 2: 2A \& 2B) in pre sowing soil it was highest in MWC $\left(49 \mathrm{mg} \mathrm{kg}^{-1}\right)$ and lowest in AWC $(35.2 \mathrm{mg}$ $\mathrm{kg}^{-1}$ ) while in post-harvest soil tissue it founded maximum in MWC (30 $\mathrm{mg} \mathrm{kg}^{-1}$ ) and minimum uptake was noted in MWF (21mg $\mathrm{kg}^{-1}$ ) (Table 1). Sharpley \& Moyer [7], revealed a diminishment in water solvent phosphorus following treating the soil of poultry excrement, apparently because of the weakening impact of the additional C sources, though Dao et al. [14], found no huge impact of fertilizing the soil on water solvent phosphorus. The mean levels for the discharge of phosphorus appeared in $\mathrm{NaHCO}_{3}$ in manure varied as AWC $>$ AWF $>$ MWC $>$ MWF (Figure 3: 3A \& $3 B)$, in pre sowing soil there was an increased concentration in AWC (69.4mg kg-1) and minimum in MWC (55.3 $\mathrm{mg} \mathrm{kg}^{-1}$ ) while in post-harvest soil the concentration were maximum in MWC (39 $\mathrm{mg} \mathrm{kg}^{-1}$ ) and lowest in MWF (30.1 $\mathrm{mg} \mathrm{kg}^{-1}$ ) (Table 1). It could be due to the use of different material present in solid waste and additives which ferrous-ferric hydrogen sulfate or alum litter treatments Donald Rollyson (1997). The concentration of $\mathrm{NaOH}$ phosphorus in manure varied as $\mathrm{MWC}>\mathrm{AWC}>\mathrm{AWF}>\mathrm{MWF}$, (Table 1) in pre-sowing soil the concentration was highest in MWC (47mg kg-1) and lowest in AWF (41 $\mathrm{mg} \mathrm{kg}^{-1}$ ) though in post-harvest that founded maximum in AWC $\left(27.5 \mathrm{mg} \mathrm{kg}^{-1}\right)$ and minimum in MWF $\left(20 \mathrm{mg} \mathrm{kg}^{-1}\right.$ ) (Figure 4: 4A \& 4B). Moore et al. [15], connected alum-treated poultry litter to pastures for a long time and found that solvent receptive $\mathrm{P}$ fixations in overflow were $75 \%$ lower than ordinary litter. Groupings of bioavailable inorganic phosphorus $\left(\mathrm{NaHCO}_{3}\right.$-IP), promptly mineralizable natural phosphorus $\left(\mathrm{NaHCO}_{3}-\mathrm{OP}\right)$, possibly bioavailable inorganic phosphorus (NaOH-IP), and conceivably bioavailable natural phosphorus (NaOH-OP) were as yet higher in the media changed with compost due to higher aggregate $\mathrm{P}$ focus in the compost. Phosphorus extracted with $\mathrm{HCl}$ in manure varied as $\mathrm{AWF}>$ AWC $>$ MWC $>$ MWF (Table 1), in pre-sowing soil it was found maximum in AWC (51.9 $\left.\mathrm{mg} \mathrm{kg}^{-1}\right)$ and minimum in MWC (25mg $\mathrm{kg}^{-1}$ ) while in post-harvest soil the concentration was highest in MWC (31 $\left.\mathrm{mg} \mathrm{kg}^{-1}\right)$ and lowest in MWF $\left(27 \mathrm{mg} \mathrm{kg}^{-1}\right.$ ) (Figure 5: 5A \& 5B). Williams et al. [16], found that corrosive P set up stable Cabound $\mathrm{P}$, so it would impossible add to the eutrophication of water sources. In any case, it can be assembled to labile portion after the promptly $\mathrm{P}$ is drained. The relation contrasts watched for the $\mathrm{NaOH}-\mathrm{P}$ division over the compost medication was basically like the $\mathrm{HCl}-\mathrm{P}$ frame. The $\mathrm{NaOH}-\mathrm{P}$ is a chemisorbed shape Williams et al. [17]. It likewise covers $P$ related with humic mixes and P sorbed to $\mathrm{Fe}$ and $\mathrm{Al}$ oxides Cross \& Schlesinger [18]. The exhaustion of water dissolvable $\mathrm{P}$ and $\mathrm{NaHCO}_{3} \mathrm{P}$ (the promptly accessible $\mathrm{P}$ ) recommend that these divisions of $\mathrm{P}$ may be lost through filtering, overflow. Limit agronomic P level was accounted for as $20 \mathrm{mg} \mathrm{kg}^{-1}$ soil by Sharpley [19]. Amounts of fractions were higher in both composted and fresh manures because of the fact that these wastes have been sequentially fractionated in original form and were not applied to the soil. The P form removed through $\mathrm{NaHCO}_{3}, \mathrm{NaOH}$ and $\mathrm{HCl}$ founded higher in composted while $\mathrm{H}_{2} \mathrm{O}$ extracted $\mathrm{P}$ was higher in fresh manure. The environmental risks of apply organic improvements depend on the total P contents as well as forms of P Sims et al. [20]. Meek et al. [22], announced an expansion in the aggregate and accessible $\mathrm{P}$ because of fertilizer application.

Table 1: Phosphorus Fractionation ( $\mathrm{mg} \mathrm{kg}^{-1}$ ) of different samples.

\begin{tabular}{|c|c|c|c|c|c|c|}
\hline \multicolumn{2}{|c|}{ Samples } & $\mathrm{H}_{2} \mathbf{O}-\mathrm{P}$ & $\mathrm{NaHCO}_{3}-\mathrm{P}$ & $\mathrm{NaOH}-\mathrm{P}$ & $\mathrm{HCl}-\mathrm{P}$ & Total P \\
\hline \multirow{5}{*}{ Manure } & AWF & 50 & 72.4 & 53 & 79 & 99.5 \\
\hline & AWC & 63 & 81.2 & 59 & 77.5 & 95 \\
\hline & MWF & 55.4 & 62 & 52.3 & 61.6 & 89.5 \\
\hline & MWC & 60.3 & 67 & 59.5 & 62.4 & 91 \\
\hline & Control & 31 & 40 & 35 & 39 & 50 \\
\hline \multirow{5}{*}{ Pre-Sowing Soil } & AWF & 42.1 & 65.2 & 41 & 41.6 & 90.1 \\
\hline & AWC & 35.2 & 69.4 & 42 & 51.9 & 88 \\
\hline & MWF & 42 & 56 & 45 & 47 & 81.4 \\
\hline & MWC & 49 & 55.3 & 47 & 39 & 89.3 \\
\hline & Control & 22 & 28 & 27 & 25 & 35 \\
\hline \multirow{5}{*}{ Post-Harvest Soil } & AWF & 29 & 34 & 25 & 28.5 & 85.4 \\
\hline & AWC & 25 & 35.4 & 27.5 & 29 & 75 \\
\hline & MWF & 21 & 30.1 & 20 & 27 & 81 \\
\hline & MWC & 30 & 39 & 25.1 & 31 & 76.6 \\
\hline & Control & 14 & 19 & 16 & 18 & 20 \\
\hline
\end{tabular}

Note: For all tables and figures AWF = The Animal Wastes Fresh; AWC = The Animal Wastes Compost; MWF = The Mixed Waste Fresh; MWC = The Mixed Wastes Compost. 
Figure 1A: Manure.
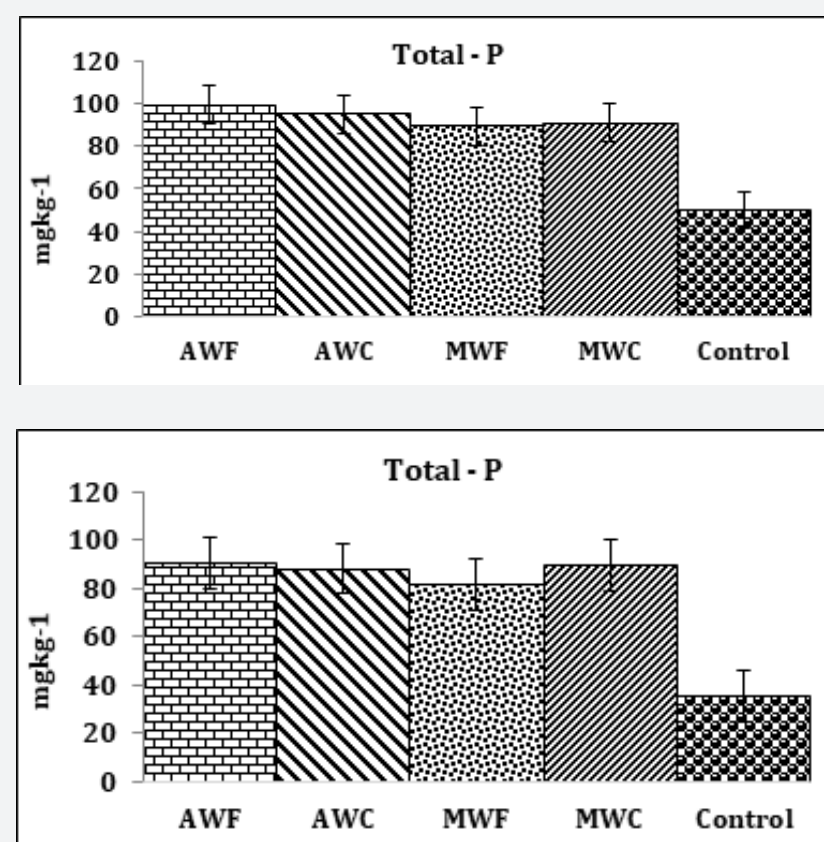

Figure 1B: Pre-sowing soil.

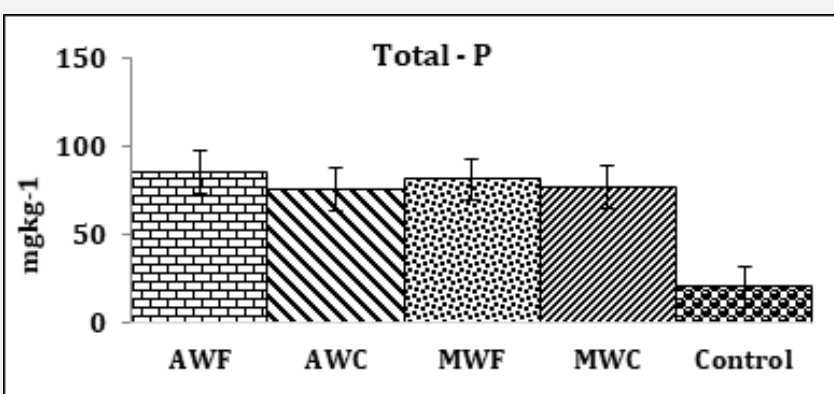

Figure 1C: Post harvest soil.

Figure 1: Double acid digestion Phosphorus.

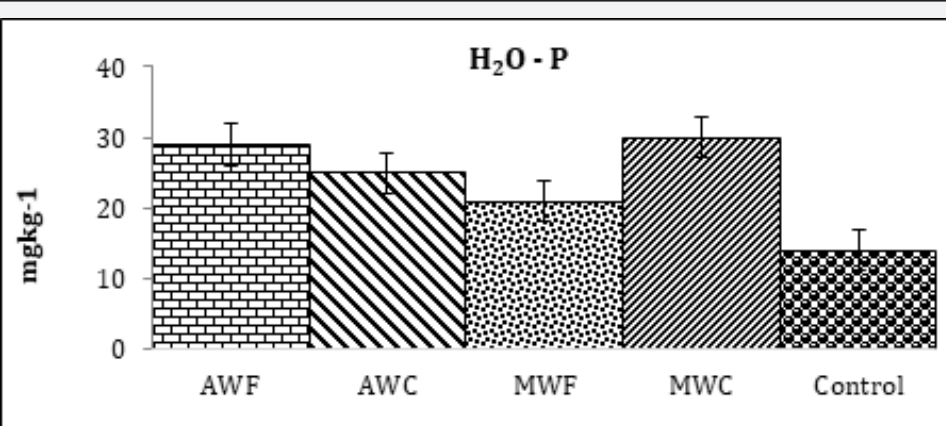

Figure 2A: Post harvest soil.

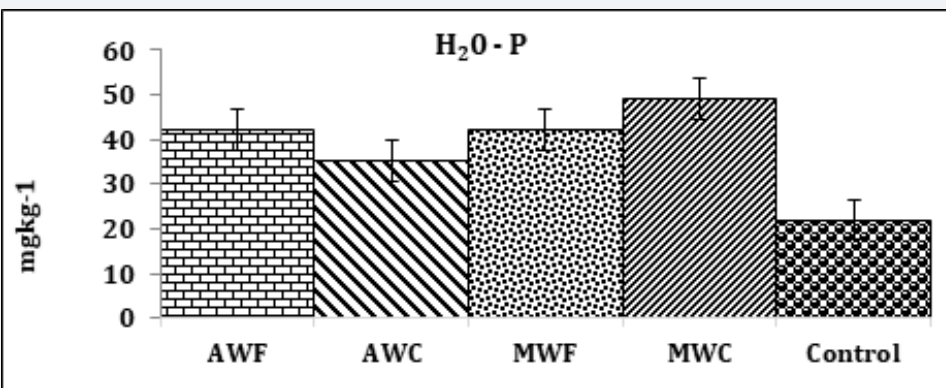

Figure 2B: Pre-sowing soil.

Figure 2: Water soluble extracted $\mathrm{P}$ fractions. 
Figure 3A: Manure.

Figure 3B: Pre-sowing soil.

Figure 3C: Post harvest soil.

Figure 3: Plant available $P$ fractions.
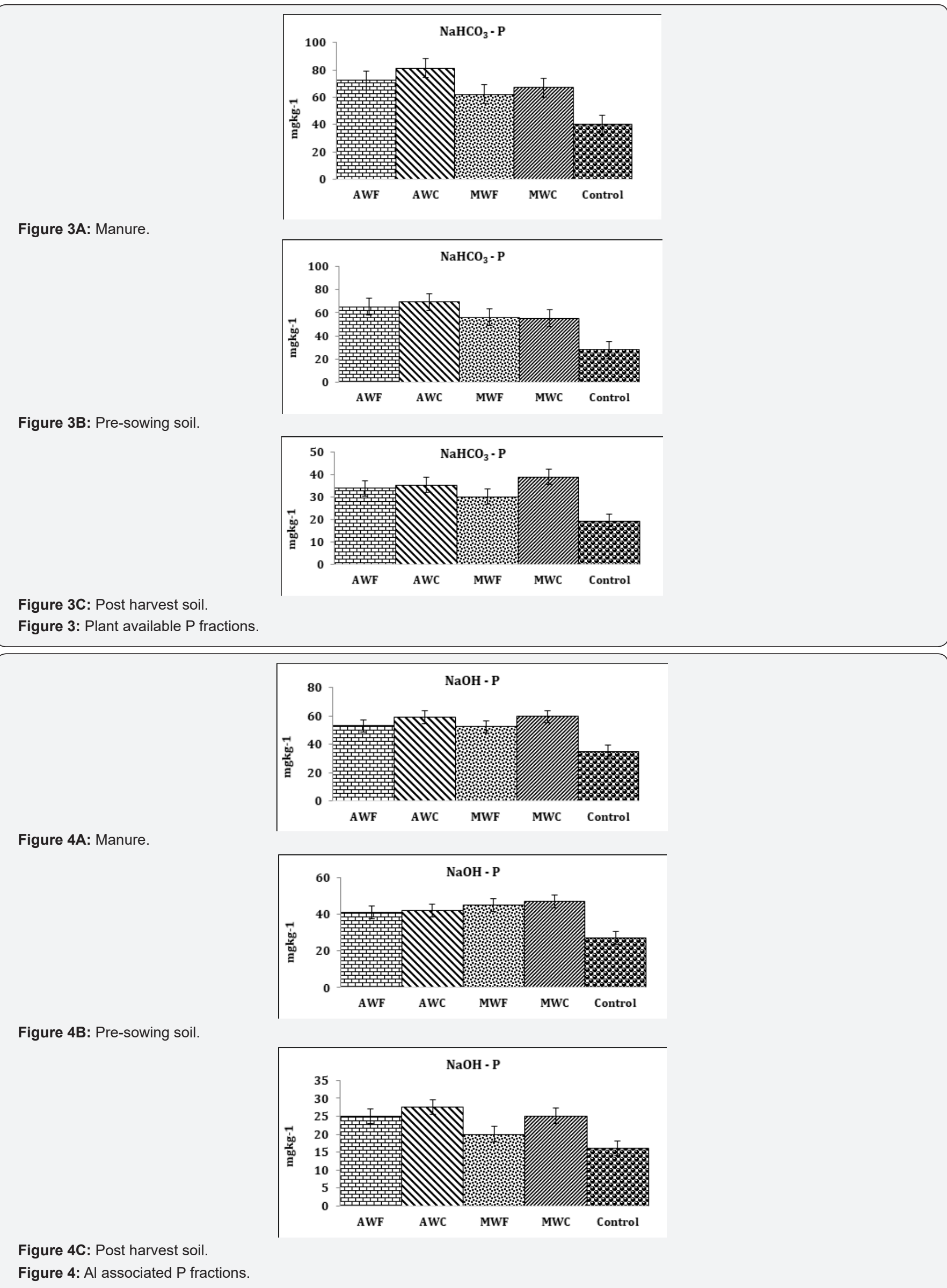


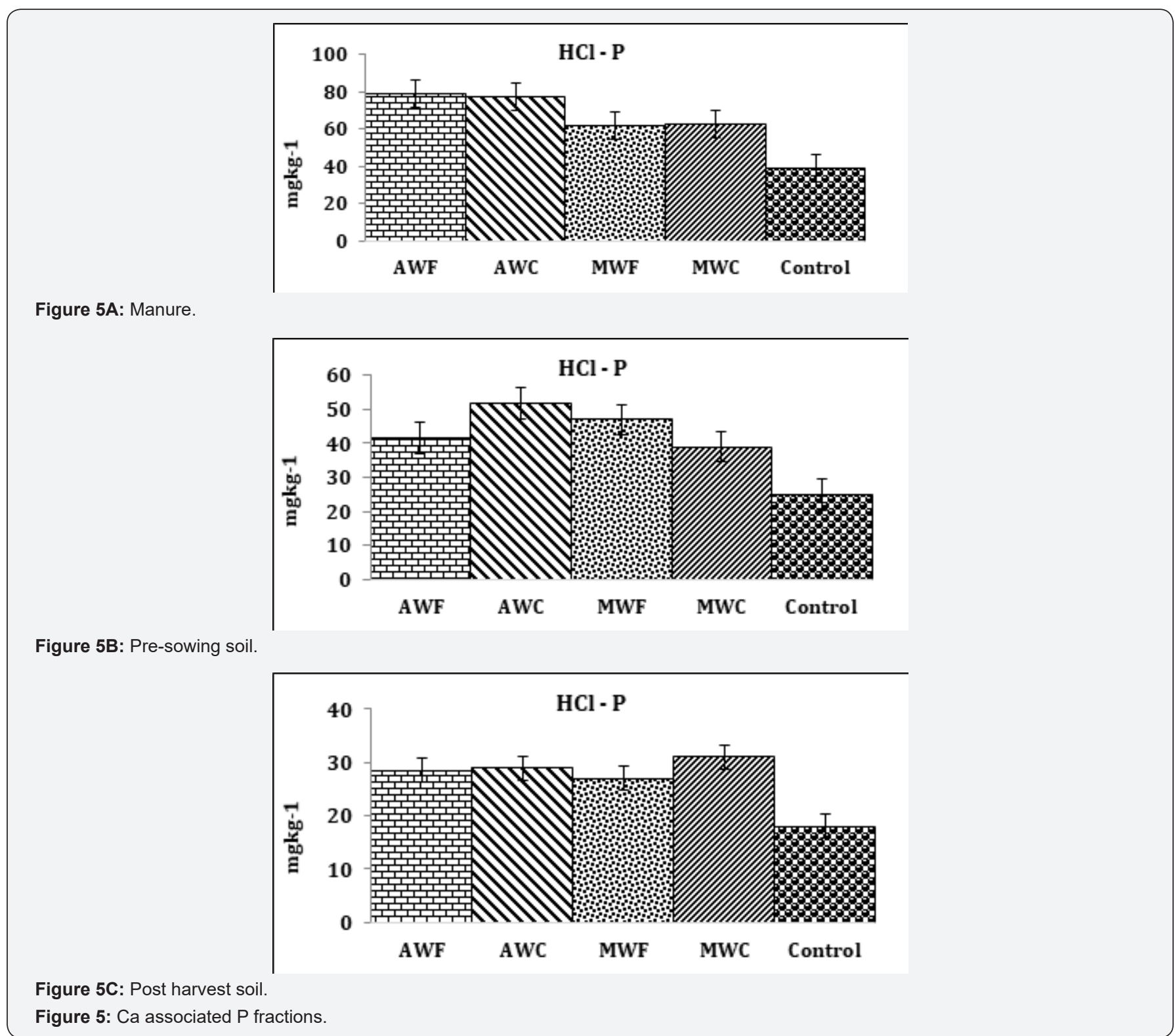

\section{Conclusion}

The objective of this study is to present information regarding assessment of the bioavailability of nutrients to maize crop from soils amended with different waste materials. Recycling of organic waste material gives an excellent phosphorus fertilizer. The characterization of solid waste and animal manure helps to provide information about the essential nutrients available to plants. The adjustments in natural issue and basic synthesis are of down to earth significance for the utilization of this material as soil correction. However, huge increments were seen in the natural substance. The general consecutive extraction for reagents significantly fluctuated for $\mathrm{P}$ arranged by $\mathrm{HCl}>\mathrm{NaOH}>\mathrm{NaHCO}_{3}>\mathrm{H}_{2} \mathrm{O}$. The $\mathrm{P}$ and different supplements accessibility expanded dynamically amid fertilizing the soil with the diminishing all the while in crisp composts. Our outcomes show that agronomic ally and ecologically essential traits related with treated the soil and non-treated the soil excrement application can be anticipated in view of $\mathrm{P}$ portions and a streamlining strategy including relapse analysis. Maintaining a strategic distance from $\mathrm{P}$ collection in the dirt is likewise a critical perspective in diminishing the danger of $P$ misfortune since biochemical procedures will eventually discharge a portion of the $\mathrm{P}$ that isn't bioavailable for the time being. We concluded that composting the soil creature excrements before arrive application can influence the structures and groupings of phosphorus. The utilization of treated the soil creature composts as soil alteration can be financially profitable and will possibly enhance the significant alarms related animal waste.

\section{References}

1. Havlin JL (2004) Technical basis for assessing phosphorus loss to surface and ground waters. J Anim Sci 82(E Suppl): E277-E291.

2. Faridullah, Yamamoto S, Irshad M, Uchiyama T, Honna T (2008) Phosphorus Fractionation in Chicken and Duck Litter Burned at Different Temperatures. Soil Science 173(4): 287-295.

3. Huang F, Chakraborty P, Lundstrom CC, Holmden C, Glessner JJG, et al. (2011) Huang et al. reply. Nature 472(7341). 
4. Benitez C, Bellido E, Gonzales GL, Medina M (1998) Influence of pedagogical and climatic factors on nitrogen mineralization in soils treated with pig slurry compost. Bioresour Technol 63: 147-151.

5. Hoitink HAJ (2000) Trends in treatment and utilization of solid wastes through composting in the United States. Proceedings of the International Composting Symposium, vol. 1. CBA Press Inc., Nova Scotia, pp. 1-13.

6. Maftoun M, Moshiri F, Karimian N, Ronaghi AM (2004) Effects of two organic wastes in combination with phosphorus on growth and chemical composition of spinach and soil properties. Journal of Plant Nutrition 27(9): 1645-1651.

7. Sharpley AN, Moyer B (2000) Phosphorus forms in manure and compost and their release during simulated rainfall. J Environ Qual 29(5): 1462-1469.

8. Faridullah, Irshad M, Yamamoto S, Ahmad Z, Endo T, et al. (2009) Extractability and Bioavailability of Phosphorus from Soil Amended with Poultry Litter and Poultry Litter Ash. Journal of Food Agriculture \& Environment 7(2): 692-697.

9. Hedley MJ, Stewart JW, Chauhan BS (1982) Changes in inorganic and organic soil phosphorus fractions induced by cultivation practices and by laboratory incubation. Soil Sci Soc Am J 46(5): 970-976.

10. Dou Z, Toth JD, Galligan DT, Ramberg CF, Ferguson JD (2000) Laboratory procedures for characterizing manure phosphorus. J Environ Qual 29(2): 508-514.

11. Ajiboye B, Akinremi 00, Racz GJ (2004) Laboratory characterization of phosphorus in fresh and oven-dried organic amendments. J Environ Qual 33(3): 1062-1069.

12. Murphy J, Riley JP (1962) A modified single solution method for the determination of phosphate in nature water. Anal Chim Acta 27: 31-36.

13. Hargreaves JC, Adl MS, Warman PR (2008) A review of the use of composted municipal solid waste in agriculture. Agriculture Ecosystems and Environment 123(1-3): 1-14.

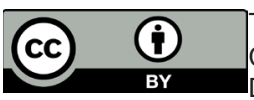

This work is licensed under Creative Commons Attribution 4.0 License DOI: 10.19080/ARTOAJ.2018.18.556057
14. Dao TH, Sikora LJ, Hamasaki A, Chaney RL (2001) Manure phosphorus extractability as affected by aluminum and iron by-products and aerobic decomposition. Journal Environmental Quality 30: 1693-1698.

15. Moore PA, Daniel TC, Edwards DK (2000) Reducing phostection of surface waters: Issues and options. J Environ Qual. phosphorus runoff and inhibiting ammonia loss from poultry manure with aluminum sulfate 29: 37-49.

16. Williams JDH, Shear, Thomas RL (1980) Availabilty to Scendes musgradncauda of different forms of phosphorus in sedimentary materials from the Great Lakes. Limnol Oceanogr 25: 1-11.

17. Williams JDH, Syers JK, Armstrong DE, Harris F (1971) Fractionation of inorganic phosphate in calcareous lake sediments. Soil Sci Soc Am Proc 35(2): 250-255.

18. Cross AF, Schlesinger WH (1995) A literature review and evaluation of the Hedley fractionation: Applications to the biogeochemical cycles of soil phosphorus in natural ecosystems. Geoderma 64(3-4): 197-214.

19. Sharpley AN, Smith SJ, Stewardt BA, Mathers AC (1984) Forms of phosphorus in soil receiving cattle feed lot waste. J Environ Qual 13: 211-215.

20. Sims TJ, Edwards AC, Schoumans OF, Simards RR (2000) Integrating soil phosphorus testing into environmentally based management practices. J Environ Qual 29(1): 60-71.

21. Faridullah, Irshad M, Yamamoto S, Eneji AE, Uchiyama T, et al. (2009) Characterization of trace elements in chicken and duck litter ash. Waste Manag 29(1): 265-271.

22. Meek BD, Graham LE, Donovan TJ, Mayberry KS (1979) Phosphorus availability in a calcareous soil after high loading rates of animal manure. Soil Sci Am J 43: 741-743.

\section{Your next submission with Juniper Publishers will reach you the below assets}

- Quality Editorial service

- Swift Peer Review

- Reprints availability

- E-prints Service

- Manuscript Podcast for convenient understanding

- Global attainment for your research

- Manuscript accessibility in different formats

( Pdf, E-pub, Full Text, Audio)

- Unceasing customer service

Track the below URL for one-step submission

https://juniperpublishers.com/online-submission.php 